\title{
ВИКОНАННЯ НАУКОВИХ ДОСЛІДЖЕНЬ ЗА ЕЛЕКТРОННИМ РЕЄСТРОМ ПАЦІЕНТІВ
}

\author{
Ю. Н. Таращенко, М. Ю. Болгов \\ ДУ «Інститут ендокринології та обміну речовин ім. В. П. Комісаренка НАМН України»
}

Розробка медичних інформаційних систем є складним та багатоступеневим завданням. Як правило, так звані «вихідні форми» (в яких, зокрема, передбачається аналіз даних) плануються ще на етапі проектування системи. Безумовно, вони в подальшому неодноразово змінюються та доповнюються. Але механізми автоматичного формування запитів в медичних інформаційних системах не є поширеними, а якщо і закладаються у функціонал системи, то переважно створюються як стандартний механізм із заздалегідь визначеними можливостями налаштування.

Водночас великі обсяги медичних даних, які підтримуються за допомогою медичних інформаційних систем, $є$ прекрасним підгрунтям для виконання наукових досліджень. Так, в клініці інституту ендокринології, електронний реєстр хворих працює вже понад 10 років та містить більше 180 тис. амбулаторних карток пацієнтів 3 результатами багаточисленних обстежень та оперативних втручань. В запропонованому дослідженні розглянуто можливості медичної інформаційної системи TherDep для виконання наукових досліджень на прикладі проведення ретроспективного аналізу даних, зокрема стосовно результатів спостереження за доброякісними вогнищевими утвореннями щитоподібної залози. На цьому прикладі наочно демонструються підходи до автоматизованого аналізу даних, переваги та проблеми на цьому шляху.

Треба зауважити, що база даних електронного реєстру пацієнтів побудована на основі реляційних таблиць. У вершині структури знаходиться таблиця амбулаторних карток. Принципово вся інформація може бути збережена або в цій таблиці, або в підлеглих, по відношенню до неї. Такими є таблиці діагнозів, обстежень, аналізів, госпіталізацій, операцій тощо. Для збереження параметрів користувачів (до яких належить вся нестандартна, зокрема вузькопрофільна організаційна та наукова інформація) використовуються так звані таблиці «номінацій», які є підлеглими до відповідних таблиць даних (амбулаторних карток, госпіталізацій, обстежень тощо). Разом із механізмом автоматичного додавання номінацій (за ключовими фразами у текстових графах), такий підхід дозволив в режимі реального часу створити формалізо-

(c) Ю. Н. Таращенко, М. Ю. Болгов ваний масив даних, зокрема пацієнтів з вогнищевою патологією щитоподібної залози. Наприклад, якщо за результатами сонографічного дослідження щитоподібної залози було визначено наявність вогнищевого утворення правої частки діаметром 15 мм, то в автоматичному, фоновому, режимі (без жодних додаткових дій користувача) створюється номінація «Вузол правої частки» та заноситься у числовому вигляді значення «15». Подібним чином зберігається інформація про об'єми часток, формалізуються цитологічні та патогістологічні висновки.

Зазначені механізми забезпечили весь обсяг роботи зі створення формалізованих даних, готових для проведення автоматизованого аналізу. Для його проведення в медичній інформаційній системі TherDep є окрема утиліта під назвою "TherDep SQL", яка дозволяє створення довільних вибірок даних за всіма наявними графами, формування списків, таблиць та розрахунку статистичної достовірності за критерієм Стьюдента. Подібних за можливостями утиліт в інших медичних інформаційних системах нами не знайдено.

Використовуючи можливості “TherDep SQL" було відокремлено групу пацієнтів із доброякісними (за даними цитологічних досліджень) вогнищевими утвореннями щитоподібної залози та простежено динаміку змін розмірів вогнищевих утворень впродовж довготривалого спостереження (максимум 13 років). Крім того, виявлено всі випадки встановлення злоякісності у цих додаткових утвореннях (при їх хірургічному лікуванні в подальшому). За ознаками відсутності щитоподібної залози чи їі часток було також виявлено випадки хірургічного лікування цих пацієнтів за межами клініки інституту. Слід зазначити, що за всіма проаналізованими пацієнтами було взято до уваги лише ті строки спостереження, які мали фіксацію у базі даних. Якщо пацієнт більше не потрапляв на обстеження (такі випадки мають місце внаслідок низки причин), то термін спостереження враховувався лише той, за який ми мали наявні дані.

На основі отриманих даних планується створення алгоритму ведення пацієнтів 3 доброякісними вогнищевими утвореннями щитоподібної залози, як такого, що базується на суттєвій доказовій базі довгост- 
рокового ретроспективного аналізу. Також планується визначення більш чітких (ніж прийняті на сьогодні світовою ендокринологічною спільнотою) показань до хірургічного лікування доброякісних вогнищевих утворень щитоподібної залози.

Висновки. Практичне використання наявних в медичній інформаційній системі TherDep можливос- тей щодо проведення наукових досліджень довело їх адекватність та достатність. Це дозволяс рекомендувати використання зазначеної системи для зберігання та обробки медичних даних у тих лікувальних установах, де поряд 3 практичним наданням медичної допомоги проводяться аналітичні наукові дослідження. 